\title{
Off-Shoring And Outsourcing
}

\author{
Simran K. Kahai, John Carroll University, USA \\ Tejinder S. Sara, Tuskegee University, USA \\ Paramjit S. Kahai, CEO Of Neo It \&Security, LLC, USA
}

\begin{abstract}
Because of a dramatic decrease in transportation and telecommunication costs, the digital revolution, and the forces of globalization, off-shoring has accelerated in the past few years. While there is little doubt that off-shoring has brought hardship to thousands of workers and communities, there is also little doubt that it has benefited many worker and communities. Today, off-shoring continues to generate considerable debate on the long-run impact. Also, there is considerable misunderstanding about this phenomenon. In this paper, the authors make a distinction among the terms outsourcing, offshore outsourcing, and off-shoring. Off-shoring has been facilitated by a deconstruction of the value chain, allowing firms to evaluate all activities as potential candidates for being performed outside the firm. Reasons for the acceleration of offshoring are outlined. An explanation of why off-shoring is not a villain for the developed economies is also provided.
\end{abstract}

Keywords: Off-shoring; outsourcing; off-shore outsourcing

\section{INTRODUCTION}

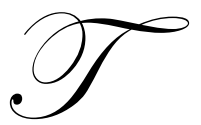

he rapid increases in offshoring services in recent years have generated considerable debate on the costs and benefits to the economies of countries engaged in these activities. Not since Ross Perot called the North American Free Trade Agreement (NAFTA) a "“giant sucking sound' of US jobs going to Mexico" has the debate on overseas jobs shipment been more heated (Freauf, 2003). At times, it even became an issue in the 2004 US Presidential election.

As with foreign competition, the intensity of the debate surrounding off-shoring ebbs and flows with the condition of the economy. In the 1970s, both US workers and companies protested against the import of Japanese cars and foreign steel. The results were ruinous quotas and union sanctions against automation in car assembly (McAllister, 1981 and Stapler, 1981). In the 1980s and 1990s, the protest was replaced by a fear of jobs being lost first to Mexico and then to China. However, as a result of a huge increase in job creation within the US, this fear was muted in the second half of the 1990s. As the US economy struggled with job losses from 2001 through 2003 , the debate on offshoring only intensified in the US.

Off-shoring has accelerated in recent years because of the way two major forces - rapid changes in technology and globalization - affected many industries in the last two decades of the $20^{\text {th }}$ century. Changes in technology, especially in the telecommunications and transportation sectors, contributed to what Cairncross and Cairncross (2001) have called "the death of distance." Falling prices of telecommunications and transportation services have enabled firms to procure material, components, and services from all around the globe, resulting in a transformation of the value chain. In addition, the sweep of globalization has opened many emerging markets that were previously closed to procurement of goods and services by firms of developed countries. In 2005 PricewaterhouseCoopers surveyed more than 1300 CEOs from around the globe to determine their perceptions of governance, risk management, and compliance. The results of the survey published in a report titled, "Bold Ambitions, Careful Choices," reflect optimism about future investment and business growth (PricewaterhouseCoopers, 2006). Off-shoring was one of the topics included in the survey. Some of the major findings on off-shoring are given in Table 1 below and Table 2 presented and discussed in a later section of this paper. As seen in Table 1, more than one third (sum of percent currently off-shoring and percent who plan to do so in the future) of the CEOs believe that off-shoring is an important business practice for their companies. These are 
important numbers, given that even though companies have been outsourcing for some time, off-shoring is a relatively new phenomenon.

Even though small companies have typically shied away from offshore outsourcing, a few have taken advantage of this new business reality. In a 2005 survey of 100 small companies by Information Week, 9 percent of the respondents said they were planning to offshore outsourcing within a year (McDougall, 2005). In another survey by CIO Insight, 27 percent of small companies were planning to offshore IT work in 2006 (Briody, 2006). Small companies are increasingly recognizing that, just like large companies, if they are going to remain competitive, they need to access the special skills and quick turnaround time that off-shoring can provide. We can expect that in future more small companies will recognize off-shoring as a viable sourcing option. Thus, any discussion of off-shoring should be of interest not only to large scale companies, but also to entrepreneurs and managers of small companies.

Table 1

Off-shoring Practices and Plans by Region (Percentage of Respondents)

\begin{tabular}{|l|c|c|c|c|}
\hline \multicolumn{1}{|c|}{ Company's Position } & United States & Europe & South America & Asia-Pacific \\
\hline Currently Off-shoring & 21 & 25 & 35 & 31 \\
\hline Not Currently Off-shoring but plan to do so in the future & 12 & 12 & 10 & 9 \\
\hline Have off-shored in the past but are not doing anymore & 5 & 3 & 4 & 2 \\
\hline Off-shoring not applicable & 58 & 54 & 49 & 53 \\
\hline
\end{tabular}

Note: Not all percentages add up to 100 due to rounding of percentages and to the exclusion of "neither/nor," "refused," and "don't know" responses.

Source: " $8{ }^{\text {th }}$ Annual Global CEO Survey, Bold Ambitions, Careful Choices," PricewaterhouseCoopers, 2006.

In an endeavor to qualitatively examine the aforementioned trends, the purpose of this paper is to (i) discuss how the recent deconstruction of value chain analysis has given way to outsourcing strategies by firms; (ii) discuss the reasons for the acceleration of offshoring in recent years; and (iii) discuss whether off-shoring is a villain in developed economies. As such, the paper is organized around these three major topic areas.

Before we proceed, it is appropriate to distinguish among the terms outsourcing, offshore outsourcing, and offshoring. We also provide some contextual background about outsourcing.

\section{Definitions}

Off-shoring is a special case of outsourcing of activities undertaken by firms. While outsourcing is the result of a deconstruction of the value chain that was developed by some researchers to explain strategies of successful companies (Dunning 1993; Hamel and Prahalad, 1994; Porter 1990), off-shoring decisions undertaken by firms are based on David Ricardo's idea of comparative advantage (Ricardo, 1821). Outsourcing must also be based on comparative advantage with the production process appropriately fragmented into intermediate products. These notions form the basis for distinguishing among the aforementioned terms.

Outsourcing. Sun Tzu, the Chinese military genius, observed 2,500 years ago that the best strategy in war is to achieve the desired results without fighting a battle (Mailsbroadcast.com, 2001). In a similar vein, outsourcing can be seen as a strategy whereby a firm achieves the desired results by collaborating with other firms, sometimes even with competitors. It is a term that refers to the practice of one firm hiring another to perform tasks that were originally performed in-house.

When a firm comes to the conclusion that its resources and capabilities are not a source of competitive advantage in a value creating activity, it might decide to purchase that activity from an external supplier. Decisions with regard to outsourcing do not take into account the nationality of the business service provider. Thus, outsourcing can refer to work provided by companies in the US or in other countries. Since outsourcing requires surrendering a significant amount of management control by the outsourcing firm to the supplier of goods and services, it must be accompanied by trust and coordination between the firms involved. 
Offshore outsourcing and offshoring. Offshoring is a special case of outsourcing, whereby a firm sends an activity to be performed by a firm in a foreign country. A distinction can be made between offshore outsourcing (offsourcing) and offshoring. Offshore outsourcing refers to the practice of sending a business function to a foreign firm in a foreign country. On the other hand, in offshoring, a foreign division or subsidiary of the parent company performs the business function.

Both offshore outsourcing and off-shoring can be in the context of manufacturing or services. In the case of manufacturing, China has emerged as a clear leader; in the case of services, it is India that is currently the leader. For example, China's manufacturing exports increased from $\$ 50$ billion in 1996 to over $\$ 400$ billion in 2003 ( The Economist, November 13, 2003) and Indian software exports increased from $\$ 747$ million in 1996 to $\$ 9.5$ billion in 2003 (Atkinson, 2004). Incidentally, most of the debate today is not around outsourcing, but around offshore outsourcing and off-shoring the activities of a firm. In order to simplify the discussions in this paper, we will refer to both these activities as off-shoring.

\section{Background}

According to $19^{\text {th }}$ century economist David Ricardo, even though geography and climate can be a source of comparative advantage for a country, skills and productivity of local workers can play an even more important role in the selection of products and services a country should specialize in. Specialization can be beneficial for both developed and less developed countries. To illustrate, Ricardo suggested that England should buy wheat from Spain and Portugal, and sell them machines and products that its workers can produce more efficiently (Ricardo, 1821). The mounting pressure from the emerging industries, coupled with Ricardo's argument, led to the abolishment of the Corn Laws in 1846. This move was a major victory for liberal trade and laid the groundwork for more liberal trade in the rest of Europe (O'Rourke and Williamson 2000). It was also a statement by England that the idea of comparative advantage should be the basis of prosperity for the country. In recognition of the fact that England was the home of industrial revolution, and its important position among the trading countries of the world in the middle of the 19th century, the zero meridian was drawn through London in 1861. This signified that England was now the political and economic center of the world. Today, due to the revolution in telecommunications, no one place on the earth has to be designated as the economic center of the world. Modern information technology reduces the need for physical contact and allows firms to locate their operations in different countries. Thus, many parts of the world can be used to provide goods and services. As a result, offshoring has become one of the most important management trends of recent times.

\section{THE DECONSTRUCTION OF THE VALUE CHAIN AND ITS IMPACT ON OUTSOURCING}

Value chain refers to the idea that a firm is a chain of activities for transforming inputs into outputs that bring value to customers. It has been used by researchers to describe how a firm organizes and performs discrete activities that add value to the production and sale of its goods and services. According to this framework, the manner in which activities such as logistics, operations, marketing, and accounting, are performed in a firm can lead to strengths or weaknesses in a firm.

The logic presented in Ronald Coase's (1937) seminal article had a significant influence on the development of value chain analysis. In line with this analysis, the growth of the modern firm is the result of management's efforts to reduce "costs of negotiating and concluding a separate contract for each exchange transaction" (Coase, 1937; p. 389). It was transaction cost minimization attempts by firms that formed the basis for their vertical integration strategies. These vertical integration strategies became the foundation for the concept of value chain.

Differences among competitor's value chains are a key source of competitive advantage (Porter, 1990). The ability of a firm to identify and exploit those activities that matter most to its performance is seen as a source of strength. Today, with reductions in transportation costs and the pervasiveness of new technologies, virtually every function or activity along a firm's value chain can be performed at various locations around the world. Under this strategy, a global firm can evaluate all activities in the value chain as potential candidates for being performed outside the firm. For many firms, this evaluation results in the outsourcing of activities, a strategy contrary to vertical integration that had been in vogue for many years. 
As stated earlier, outsourcing is the purchase of a value creating activity from an external supplier. Firms undertake outsourcing because it is unlikely that they have the resources and capabilities to carry out all activities better than their competition (Hitt, Ireland, and Hoskisson, 2003). By outsourcing activities for which firms do not have a competitive advantage, they can concentrate on refining activities in which they have core competencies. As an illustration, Dell outsources most of its manufacturing, thereby freeing its resources to concentrate on the activity of online sales, an activity in which it has a core competency.

Core competencies have been defined as the collective knowledge and skills an organization has that distinguish it from its competitors (Meredith and Shafer, 2001). These core competencies become building blocks for core capabilities that give organizations a strategic advantage over their competitors in delivering new products and services. Since no organization can have core competencies in all primary and secondary functions ${ }^{1}$, outsourcing involves subcontracting of activities or services that are not strategically important to a firm. Outsourcing is like renting. In the case of outsourcing, the firm is renting another firm's capabilities (Hamel, Doz, and Prahalad, 1989). As a result, a firm can outsource non-strategic activities without loosing competitiveness. Outsourcing helps a firm concentrate on using its core competency to gain a competitive advantage.

\section{Outsourcing of Manufacturing}

For the past three decades, it was manufactured goods that were targeted for international outsourcing and offshoring. This is because over 75 percent of world trade comprises manufactured goods. The trend in offshoring services emerged only in the late 1980s and 1990s (Atkinson, 2004). In the early years, Ireland was a popular destination for service offshoring by US companies, where there are currently about 40,000 customer service jobs (Atkinson, 2004). More recently, though, countries like India have grabbed a major chunk of service outsourcing, especially in areas like customer service in call-center and IT-related businesses.

The last two decades of the twentieth century witnessed a sharp increase in international outsourcing and off-shoring of manufactured goods. As a result we have witnessed substantial deconstruction of the value chain in the manufacturing sector of the US economy. The main factors contributing to international outsourcing and offshoring have been opening of a number of developing countries, world-wide improvements in productivity, and fall in cost of logistics. For example, share of logistics in the US GDP fell from 14.5 percent in 1982 to 8 percent in 2006 (The Economist, June 17, 2006). The cost of shipping on sea-lanes has also dropped significantly. According to Levinson, the cost of loading a ton of cargo fell from an average of $\$ 5.83$ in 1956 to $\$ 0.16$ in 2006 (Levinson, 2006). In addition, unprecedented global reach of delivery companies such as FedEx, UPS, and DHL has led to rapid decline in international airfreight rates (Hummels, 1999). Under pressure to reduce cost and increase market share, firms from the US and other countries have taken advantage of the reduction in transportation cost by outsourcing to subcontractors who can perform operations at lower costs.

\section{The Role of Information}

The move to outsourcing has been bolstered by what Evans and Wurster (1999) refer to as the changing "economics of information." According to their argument, information is the glue that holds value chains together. But the development of Internet and other communication channels has enabled almost cost-free exchange of information. Firms can now communicate with suppliers all over the globe. This means that the traditional trade-off between "richness" and "reach" is not important for many functions along the value chain. "Richness" refers to the quality of information that emphasizes attributes such as accuracy, currency, relevance, etc. "Reach" refers to the number of individuals who share the information. A firm concentrating on richness in information can interact with only a limited number of individuals or businesses and maintain the integrity of information flow. Conversely, a firm emphasizing reach is trying to interact with a large number of individuals or businesses.

Until recently, firms had to find a trade-off between these two attributes of information. Communicating rich information meant that people worked in close proximity or shared channels that were not available to a

\footnotetext{
${ }^{1}$ In the concept of a firm as a value chain, primary functions are those that are involved directly in providing products. Secondary functions are those that are needed to manage and control processes.
} 
majority of individuals. On the other hand, sharing information with a large number of individuals or businesses meant a sacrifice of quality of that information. Since the sharing of rich information with a large number of individuals is costly, the strategy of firms has been to construct value chains and move rich information within the boundaries of the firm.

The recent innovations related to the Internet, advances in telecommunications technology, ease and pervasiveness of connectivity, and development of common information standards have eliminated the trade-off between richness and reach of information. High quality information can now be shared by an ever increasing number of individuals and firms. As a result, there has been a tremendous decrease in the transaction costs of sharing information with entities outside the firm. In many cases, this means that value chains are not relevant tools in strategies of firms. This collapse of the value chain in businesses has encouraged and accelerated the outsourcing of non-strategic activities.

\section{WHY HAS OFFSHORING PICKED UP IN RECENT YEARS?}

History has shown us that it takes time - in some cases decades - for innovations to be fully incorporated into the strategies of firms. Firms have to change their business practices to take advantage of new technologies that result from innovation. For example, the first steam engine was built in 1705, but it became a useful tool for locomotion and production only in the 1800s. Another example is the commercial applications of electricity. Even though Thomas Edison demonstrated the commercial uses of electricity in 1870s, it took firms a number of years to reorganize and take advantage of labor savings resulting from the use of electricity in manufacturing. Subsequently, it was decades before electricity delivered meaningful productivity gains. By 1910, only one third of the factories used electricity to drive their machinery (Micklethwait and Wooldridge, 2000). Similarly, productivity gains from investment in information technology (IT) have only begun to be realized recently (The Economist, Sept. 13, 2003).

The costs of telecommunications and transportation, too, have been falling for decades, but their potential impact on offshoring is being realized only recently. In 1930, the cost of a telephone call between New York and London was $\$ 300$ in 1996 dollars. In 1996, it was about \$2. The cost of a one-minute telephone call from India to the US fell by $80 \%$ between 2001 and 2003. International rates to the world's biggest business markets fell by $50 \%$ in just 2000 (Wall Street Journal, March 11, 2004). Today, because of the use of IT, the cost of international calls is practically zero. The Internet and mobile phones have eliminated the distance between points on the globe. In section "Outsourcing of Manufacturing" discussed earlier in this paper, we had provided some evidence that international transportation costs for goods have been falling in the past few decades.

The use of container ships has drastically reduced the time and cost of moving goods around the globe. As a result, firms are able to source components and products from a variety of countries. In addition, the use of new technologies and strategies for worldwide delivery by companies such as FedEx and UPS has allowed firms to offshore the manufacturing of their components and become efficient through the use of just-in-time inventory systems.

The intense competitive pressure in many industries today is forcing companies to find ways to cut costs. The emergence of a large number of English-speaking low-cost workers in countries such as India and Philippines has prompted companies to offshore service jobs to those countries. Even though low labor costs have existed for many years in these and other developing countries, it is the rapid advances in technology and global communications that has made offshoring attractive, albeit only in the past few years. Although the Internet has been an important enabling factor, it is the advances in digitalization, whereby a firm can break jobs into smaller pieces, that allow firms to allocate them to the most efficient and cost-effective locations. In the early years, inexpensive labor in the form of a large number of immigrants migrated to the US to work in technology fields. But now, innovations in telecommunications and transportation allow companies to send work to workers in other countries. Today, therefore, only a few jobs may need to be done on-site. 


\section{IS OFFSHORING A VILLAIN?}

Ever since Industrial Revolution, automation has been considered a villain for job growth. It was contended that increases in productivity resulting from automation would result in increased joblessness. However, data indicate that there was an increase of 72 million jobs during the last four decades, an increase of 125 percent (Wall Street Journal, March 23, 2004). As jobs were disappearing in some sectors of the economy during this period, they were being replaced by new jobs that did not exist before in sectors such as IT, financial services, and health care. This trend is expected to continue in the future. It is predicted that by 2015 , the US economy will create 22 million jobs (Baily and Farrell, 2004). Offshore jobs, however, are expected to be only a small percentage of the total jobs created by US companies.

Fear about job losses due to off-shoring may also be somewhat exaggerated. Most job losses from 2000 to 2004 were not due to off-shoring, but due to a recession. According to government statistics, off-shored jobs are responsible for well under one percent of those signed up as unemployed (The Economist, March 13, 2004). A report released by the Department of Labor on June 10, 2004, found that in the first quarter of 2004, only 4,633 out of a total of 182,456 job losses could be attributed to off-shoring. This represents only 2.5 percent of the total job losses during this period (New York Times, June 11, 2004). The report did not analyze the effect on wages in the industries that lost jobs to off-shoring. But it has been documented by others that off-shoring mostly affects wage levels in lower skilled manufacturing occupations (Atkinson, 2004). By the end of 2003, only three to four percent of outsourcing by American companies was done to offshore locations, and only 40 percent of Fortune 1000 firms are involved in any kind of off-shoring activities (The Economist, December 31, 2003). Thus, so far off-shoring seems to be a large company phenomenon.

The fear of offshoring may also be exaggerated as not all jobs are suitable for offshoring. Any job that can be reduced to a series steps or rules is a good candidate for offshoring. These include processing of medical insurance and bills, medical transcription, animation, insurance, architectural designs and drafting, desktop publishing, telemarketing, financial analysis, accounting and book keeping, and tax preparation. On the other hand, jobs requiring human contact or complex skills are less likely to be outsourced.

\section{Net Gain for the US Economy}

Some recent studies have supported the notion that off-shoring could result in a net gain for the US economy. A study released in March 2004 by Global Insight predicted that US businesses will save $\$ 20.9$ billion between 2003 and 2008 by using offshore services in IT (McDougal, 2004). The study also predicted that the US gross domestic product (GDP) will be $\$ 124.2$ billion higher in 2008 than it would be if offshore resources were not utilized by US businesses. The reason given for this increase in the GDP is that off-shoring will lower costs for businesses, which, in turn, will lead to increases in investment and other economic activity. In another study, Catherine Mann of the Institute for International Economics has calculated that cost savings due to global production of information technology hardware added \$230 billion to the US GDP between 1995 and 2002 (Mann, 2003). Mann believes that sourcing more affordable information technology from cheaper countries will create a second wave of productivity growth in parts of the economy that have not benefited from off-shoring. According to Mann this should be especially true of health care industry and small companies in different sectors of the economy. A 2004 study by Karoly and Panis at Rand Corporation came to the conclusion that by using offshore sites US companies were able to reduce cost and time by substantial amounts (Karoly and Panis, 2004). Another study prepared by McKinsey Global Institute (2003) came to the conclusion that the US economy receives $\$ 1.12-\$ 1.14$ in benefits for every dollar spent on off-shoring to India. Again, the study contends that the savings will let companies invest in new technologies and products, leading to job creation and economic expansion.

The debate on job losses due to offshoring often ignores job gains associated with "insourcing," a term used to describe Americans working in the US for foreign companies. The economic logic used by US companies to create jobs overseas also motivates foreign companies to create jobs in the US. For example, 6.5 million Americans work for foreign companies. Toyota provides high wage employment to more than 30,000 US workers (Atlanta Journal-Constitution, May 2, 2004). In 2003, Honda increased manufacturing employment in the US by 15 percent (Atkinson, 2004). Tata Consulting Services, headquartered in Bombay, India, has about 7,000 of its 30,000 total 
employees located in the US. Infosys, an Indian software company with revenues of over $\$ 1$ billion, has set up its own consulting arm in the US and plans to hire 500 workers in three years (Atlanta Journal-Constitution, May 2, 2004).

There has also been a concern that offshoring will lower wages in the US as companies buy or produce goods and services overseas. But it misses the point that many foreign industries such as pharmaceuticals, electronics, and automobiles have been creating high-paying jobs in the US. In addition, the concern about lower wages does not distinguish between money wages and real wages. One of the results of offshoring to low-cost countries is lower cost of goods and services available to US workers. Even though wages might be lowered in industries directly affected by offshoring, it can raise the overall real wages in the economy. As an illustration, American consumers have benefited from lower-priced computers manufactured from components offshored by US computer manufacturers. The results of the Global CEO survey by PricewaterhouseCooppers (discussed earlier) indicate that off-shoring is viewed as a cost cutting measure. Data in Table 2 shows that CEOs around the globe believe that off-shoring helps to reduce costs and increase competitiveness of their companies. In their responses 70 percent (sum of somewhat agree and strongly agree) of the global CEOs believe that off-shoring helps to reduce costs, a higher response than that given to any other statement. Closely related to cost reduction, increasing competitiveness comes in second (65 percent)

Table 2

Value of Offshoring

(Percentage of Respondents)

\begin{tabular}{|l|c|c|c|c|}
\hline Perception of Offshoring & Strongly Disagree & Somewhat Disagree & Somewhat Agree & Strongly Agree \\
\hline Helps to reduce costs & 2 & 4 & 34 & 36 \\
\hline Makes companies more competitive & 2 & 5 & 38 & 27 \\
\hline Raises operational risk & 6 & 11 & 37 & 12 \\
\hline Raises reputational risk & 11 & 17 & 25 & 9 \\
\hline
\end{tabular}

Note: Not all percentages add up to 100 due to rounding of percentages and to the exclusion of "neither/nor," "refused," and "don't know" responses.

Source: " $8{ }^{\text {th }}$ Annual Global CEO Survey, Bold Ambitions, Careful Choices," PricewaterhouseCoopers, 2006.

\section{CONCLUSIONS}

The current debate on offshoring quite often focuses on short-term job losses, ignoring long-term benefits to consumers and businesses. Over the years, some have made similar arguments about the costs to a nation from global trade. But the boom in international trade in the last three decades of the $20^{\text {th }}$ century brought unprecedented economic growth around the globe. During this period, the volume of international trade in goods and services expanded from $\$ 200$ billion to $\$ 6.8$ trillion (Czinkota, Ronkainen, and Moffet, 2004). This growth in value of trade greatly exceeded the value of world output of goods and services, and contributed to higher purchasing power for consumers in the US and other countries around the globe.

Offshoring can also provide opportunities to firms in many countries to increase their specialization in products and services for which they have comparative advantage. In doing so, these firms realize cost reductions by utilizing unexploited economies of scale. As long as economies of scale continue to be present, the firms performing the service or producing the product will have incentive to increase their activities. This results in cost reduction in all involved countries, which, in turn, results in lower prices for goods and services consumed around the world. Thus, offshoring has a potential to raise living standards in all countries involved and to increase real wages of workers. We may, therefore, conclude that offshoring is not a zero sum game. In the long run, it is a game where net gains are positive. That is, the winnings of winners in all countries involved far exceed the losses of losers in those countries.

One should not believe that there are no disadvantages to offshoring. Offshoring does lead to lower wages and job losses for some workers in the economy. And it is difficult to put a quantitative value on the pain suffered by workers in industries and communities directly affected by offshoring. But the job loss/gain equation has long 
been a part of the economic history of the US. In a dynamic economy, there will always be job losses as businesses use strategies to become more efficient and take advantage of new opportunities. As was pointed out earlier, forces of automation and globalization brought labor market disruptions in some sectors of the economy. In the past few decades firms moved to low-wage Southern states from the industrial Northeast and Midwest states. But, after an initial decline, the economies of the states that lost jobs to the South recovered by developing new industries.

The major challenge, thus, to policymakers is to make sure that workers adversely affected by offshoring share in the benefits from offshoring. Public policy programs that invest in training and provide unemployment compensation to affected workers can ensure that the US economy remains competitive in developing new technologies and creating high value-added jobs.

\section{REFERENCES}

1. Atlanta Journal-Constitution, May 2, 2004.

2. Atkinson, R. D. "Understanding the Offshoring Challenge." Policy Report, Progressive Policy Institute, Washington D.C., 2004. Retrieved October 1, 2004 from http://www.ppionline.org/documents/Offshoring 0504.pdf.

3. Baily, Martin N. and Farrell, Diana, "Exploding the Myths about Offshoring." McKinsey Global Institute, McKinsey \& Company, April 2004.

4. Briody, Dan, "Small Businesses Struggle to Offshore." CIO INSIGHT, March 6, 2006.

5. Cairncross, F. and Cairncross, F. C. The Death of Distance: How the Communications Revolution Is Changing our Lives. Boston, MA: Harvard Business School Press, 2001.

6. Coase, R. H. “The Nature of the Firm.” Economica N. S., 1937. pp. 386-405.

7. Czinkota, M. R., Ronkainen, I.A., and Moffett, M. H. International Business. Mason, OH: South-Western Publishing, 2004.

8. Dunning, John H. Multinational Enterprises and the Global Economy, Boston, MA: Addison-Wesley, 1993.

9. Economist, The. September 13, 2003.

10. Economist, The. November 13, 2003.

11. Economist, The. December 31, 2003.

12. Economist, The. March 13, 2004.

13. Economist, The. June 17, 2006.

14. Evans, Philip and Wurster, Thomas S. Blown to Bits: How the New Economics of Information Transforms Strategy. Boston, MA: Harvard Business School Press, 2000.

15. Freauf, B. "The Giant Sucking Sounds In Washington, D.C.” June 9, 2003. Retrieved October 1, 2004, from http://www.newswithviews.com/Betty/Freauf28.htm.

16. Hamel, G., Doz, Y.L., and Prahalad, C.K. Collaborate with Your Competitors - and Win, Harvard Business Review, 1989.

17. Hamel, Gary and Prahalad, C.K. Competing for the Future. Boston, MA: Harvard Business School Press, 1994.

18. Hitt, M. A., Ireland, R.D., and Hoskisson, R.E. Strategic Management: Competitiveness and Globalization. Mason, OH: South-Western Publishing, 2004.

19. Hummels, David, "Have International Transportation Costs Declined?" University of Chicago, July, 1999

20. Karoly, Lynn A. and Panis, Constantijin, W.A., "The $21^{\text {st }}$ Century at Work: Forces Shaping the Future Workforce in the United States." Rand Corp. Santa Monica, California, 2004.

21. Levinson, Marc, The Box: How the Shipping Container Made the World smaller and the World Economy Bigger. Princeton University Press, Princeton, N.J. 2006.

22. Mailsbroadcast.com. "Sun Tzu - Art of War, January 2001.” Retrieved October 1, 2004, from http://www.mailsbroadcast.com/the.artofwar.htm.

23. Mann, Catherine L. Globalization of IT Services and White Collar Jobs; The Next Wave of Productivity Growth, Institute for International Economics, December 2003.

24. McAllister, Eugene J. "Import Quotas: An Unwise Solution.” Research Backgrounder \#135, March 18, 1981, Heritage Foundation, Washington D.C.

25. McDougal, Paul. "The Offshore Equation.” Information Week, September 14, 2004. 
26. McDougal, Paul. "Small-Scale Offshoring." Information Week, July 25, 2005.

27. McKinsey Global Institute. Offshoring: Is it a Win-Win Game? McKinsey \& Company, San Francisco, 2003.

28. Meredith, J.R. and Shafer, M. S. Operations Management for MBAs. Hoboken, NJ: Wiley Publishers, 2001.

29. Micklethwait, John and Wooldridge, Adrian. A Future Perfect. New York, NY: Crown Business Publishers, 2000.

30. New York Times, June 11, 2004.

31. O'Rourke, Kevin H. and Williamson, Jeffery G. When Did Globalization Begin? Working Paper 7632, National Bureau of Economic Research, Cambridge, Massachusetts, 2000.

32. PricewaterhouseCoopers, $8^{\text {th }}$ Annual Global CEO Survey, Bold Ambitions, Careful Choices. PricewaterhouseCoopers, 2006.

33. Porter, Michael. The Competitive Advantage of Nations. New York, NY: Free Press, 1990.

34. Reich, Robert B. "Nice Work if You Can Get It.” Wall Street Journal, December 26, 2003.

35. Ricardo, David. On the Principles of Political Economy and Taxation. John Murray, London, 1821.

36. Stapler, W.F. "Car-Import Quotas Are Not the Answer," The New York Times, February 27, 1981.

37. Wall Street Journal, March 11, 2004.

38. Wall Street Journal, March 23, 2004. 
NOTES 